\title{
Nations meet to plan for world nuclear fusion effort
}

Munich

NATIONS from East and West took steps toward an unprecedented cooperation in nuclear fusion in an agreement signed in Vienna on 19 October.

Representatives from the Soviet Union, Europe, Japan and the United States agreed to meet in Garching, West Germany, for at least four months a year for three years, starting in April 1988, to coordinate planning for the International Thermonuclear Experimental Reactor (ITER). One purpose of such a reactor would be to determine if nuclear fusion is a technically feasible source of energy. Garching is the site of the West German Max Planck Institute for Plasma Physics.

The four partners will not decide until 1990 whether to build a common fusion reactor and, if so, where. Nevertheless West German fusion expert Siegfried von Krosigk of the Research Ministry said that the ITER agreement would give a "tremendous advantage" to all the partners, "regardless of whether a common reactor is built or not."

Willy Helin, a spokesman for the European Economic Community (EEC), said that the EEC agreed to participate provided that the Next European Torus (NET) is not limited in any way by ITER. NET is also supposed to demonstrate the

technical feasibility of fusion power. Helin said that the EEC would welcome the possibility that an ITER reactor, if one is agreed upon, might be built in conjunction with NET. NET is not due to be constructed until the early 1990 s and no site has as yet been selected.

Garching was selected as a meeting place over sites in Japan and the United States, and the process of elimination used may give an indication of how an international fusion reactor, should one be built, may some day find a home.

The Japanese site at Naka was eliminated because a new building would have had to be constructed and because the access to the international airport at Narita was poor. The US site at Lawrence Livermore Laboratories in California would have fulfilled the technical needs of the group - in particular scientific facilities already involved in fusion research but Soviet insistence on a European site left only Garching.

The idea of a worldwide collaboration in fusion energy arose at the 1985 Geneva meeting of Mr Mikhail Gorbachev and $\mathrm{Mr}$ Ronald Reagan. The decision by Gorbachev and Reagan to plan the next steps in fusion research together has eventually led to the ITER agreement.

Steven Dickman

\section{Relief at deal on Europe's research programme}

\section{Brussels}

THE European Community finaliy achieved an agreement on its five-year Framework programme of research at last week's research council, but not without being reminded that the British government, largely responsible for the nine month's delay in settling the issue, retains the right to make further trouble at the end of the year.

The research council meeting on 28 September was sober, efficient and so quick that many of those present, expecting the adjournment which has been a tradition since the British presidency in the second half of 1986 , were not there at the end.

What the council agreed was a budget of 5,396 million $\mathrm{ECU}(1 \mathrm{ECU}=£ 0.69)$ for the period until the end of 1991, together with a carry-over sum of 1,084 million ECU. But 417 million ECU of the new money has been frozen, on British insistence, pending unanimous agreement on the European Communities' budget at the summit meeting fixed for Copenhagen in December.
Last week's council specifically agreed to spend 500 million ECU on the RACE programme of telecommunications technology in the five years beginning on 1 June as well as to commit 65 million ECU to medical and health research (including 14 million ECU for AIDS).

The Communities' information technology programme ESPRIT is also now in funds, although a detailed list of the projects for the second phase of the programme (called ESPRIT II) will not be approved until the next council meeting planned for 30 November.

Last week also saw a celebration in Brussels of ESPRIT's achievements so far at which Europe's West German research commissioner, Karl-Heinz Narjes, compared the treatment of the research budget unfavourably with various other spending items that "place an excessive strain on the budget"; while Jean Stern, who is the chairman of the French electronics company Bull, complained of the political climate that had compelled "a forceps birth" for ESPRIT II.

Bernard Conlon

\section{Surrogacy agencies shut}

Paris

Michèle Barzach, the French minister for health and the family, has instructed the Keeper of the Seals to close within two weeks the three surrogacy agencies now operating in France. According to Barzach, the agencies - Alma Mater, Sainte-Sarah and Anias - contravene French civil law.

Under clause 351 of civil law, it is an offence for an individual to incite a woman to enter into an agreement to abandon her child. Dr Monique Vigy, writing in the French daily Le Figaro, points out that surrogacy cannot be described as a "scientific solution to infertility" - which would be legal. Neither the production of a sample of sperm by a man, nor its introduction into the neck of the uterus, could be defined as depending upon new medical techniques, Vigy argues.

P.C.

\section{International collaboration \\ London}

THE Upjohn pharmaceutical company has embarked on a new collaborative venture with European academic institutions in an attempt to identify products with the potential for commercial exploitation. The first of a series of 'European Discovery Centres' was formally established last week between Upjohn, University College, London and the Centre Paul Broca de I'INSERM in Paris. Upjohn will support each centre for up to five years, with a staff of up to 20 people to carry out the research, which will be done in the host institution. Ultimately Upjohn hopes to spend around US \$10 million annually to support work in ten discovery centres. Upjohn will have exclusive rights to inventions derived from the collaborations.

S.L.H

\section{Cornell site moved \\ Washington}

AFTER stirring up a storm of controversy, Cornell University in Ithaca, New York, has agreed to move the proposed site for the new building that will house the Cornell supercomputing centre (see Nature 329,$280 ;$ 1987). The university's first choice for a site would have cut into the tree line above Cascadilla gorge, one of several gorges that slice through the campus. The new building plan calls for demolishing Grumman Hall and building the new structure on top of it, moving the building away from the gorge.

The old building was estimated to cost $\$ 29$ million. The university expects the new design will cost $\$ 30$ million.

J.P.

Lawrence Berkeley: Correction THE centres for sequencing the human genome for which the US Department of Energy has allowed in its budget (see Nature $329, \mathbf{2 8 0} ; \mathbf{1 9 8 7}$ ) are at Los Alamos and Lawrence Berkeley National Laboratories. There is no centre at Lawrence Livermore National Laboratory. 